\title{
Identification of differential hepatic proteins in rare minnow (Gobiocypris rarus) exposed to pentachlorophenol (PCP) by proteomic analysis
}

\author{
Yanjun Fang ${ }^{\mathrm{a}, 1}$, Xianjun Gao ${ }^{\mathrm{b}, 1}$, Jinmiao Zha ${ }^{\mathrm{c}}$, Baoan Ning ${ }^{\mathrm{a}}$, Xiaoli $\mathrm{Li}^{\mathrm{a}}$, Zhixian Gao ${ }^{\mathrm{a}, *}$, Fuhuan Chao ${ }^{\mathrm{a}}$ \\ a Institute of Hygienic and Environmental Medicinal Science, A Key Laboratory of Risk Assessment E Control for Environment E' Food Safety, Tianjin 300050, China \\ ${ }^{\mathrm{b}}$ Research Center of Basic Medical Sciences, Tianjin Medical University, Tianjin 300070, China \\ ' State Key Laboratory of Environmental Aquatic Chemistry, Research Center for Eco-Environmental Sciences, Chinese Academy of Sciences, Beijing 100085, China
}

\section{A R T I C L E I N F O}

\section{Article history:}

Received 15 January 2010

Received in revised form 11 August 2010

Accepted 13 August 2010

Available online 21 August 2010

\section{Keywords:}

Pentachlorophenol

Rare minnow

Liver

Proteome

QRT-PCR

\begin{abstract}
A B S T R A C T
Pentachlorophenol (PCP) is a ubiquitous contaminant that has been shown to lead to hepatoxicity and is implicated in the incidence of liver tumors in human. A number of previous studies have described the toxic effects of PCP based on conventional toxicological indices. However, little evidence on protein levels is available at present. For further understanding of mechanisms of action and identifying the potential protein biomarkers for PCP exposure, two-dimensional electrophoresis coupled with mass spectrometry has been used to identify proteins differentially expressed in the livers of rare minnow (Gobiocypris rarus) following PCP exposure of $0.5,5,50 \mu \mathrm{g} / \mathrm{L}$. After comparison of the protein profiles from treated and control groups, 39 protein spots were found altered in abundance ( $>2$-fold) from male and female PCP-treated groups. Matrix-assisted laser desorption/ionization (MALDI) tandem time-of-flight mass spectrometry (TOF/MS) analysis allowed the unambiguous identification, and 18 protein spots were identified successfully, 12 proteins in females and 6 proteins in males, respectively. These proteins were involved in transport, metabolism, response to oxidative stress and other biological processes. Of these proteins, four differentially expressed mRNA encoding proteins underwent quantitative analysis by quantitative real-time PCR (QRT-PCR). The consistent and discrepant results between mRNA and protein levels suggested that complicated regulatory mechanisms of gene expression were implicated in the response to PCP exposure. In addition, marked gender differences in response to PCP have been described from the comparison of the male and female liver protein profiles.
\end{abstract}

(c) 2010 Elsevier Ireland Ltd. All rights reserved.

\section{Introduction}

The chlorophenol chemicals (CPs) are toxic environmental pollutants that are considered to be ubiquitous due to improper disposal (Chen et al., 2004), of all the CPs, pentachlorophenol (PCP) had been heavily used to control termites and protect wood from fungal-rot and wood-boring insects throughout the world. Acute exposure to high doses of these chlorophenols especially PCP is often lethal (WHO, 1987). PCP is stable and persistent in the environment, including air, water and soil, and it also can be absorbed into the body by ingestion, inhalation and through the skin, which has been associated with an increased risk of human and rodent carcinogen (McConnachie and Zahalsky, 1991).

Some environmental pollutants affect via a specific mechanism of toxicity such as the uncoupling of oxidative phosphorylation, thus affecting the regulation of energy metabolism. PCP is a pow-

\footnotetext{
* Corresponding author. Fax: +862284655060.

E-mail address: yanjunfang1973@163.com (Y. Fang).

1 These authors contributed equally to this work.
}

erful uncoupler of oxidative phosphorylation. In current reports it suggested that tetrachlorohydroquinone (TCHQ), as a metabolite of PCP in liver (Juhl et al., 1985; Renner and Hopfer, 1990), may enhance toxicity and carcinogenicity of PCP, since it is capable of inducing oxidative damage (Wang and Lin, 1995). The mechanisms of toxicity induced by PCP to mammals and humans have been studied in vivo and in vitro (Chen et al., 2004). PCP may be a promoter of carcinogenesis in rodents (Chhabra et al., 1999), the malignant lymphoma and leukemia have been associated with occupational exposures to PCP in humans (Roberts, 1990) and endocrine disrupting activities (ATSDR, 2001; Proudfoot, 2003), which may affect the serum testosterone (EROD and GST activity) levels in crucian carp (Zhang et al., 2008). The lysosome destabilization is an early cytotoxic response that precedes the mitochondrial dysfunction in mammalian Vero cells exposed to pentachlorophenol (Fernández Freire et al., 2005). PCP might be involved in carcinogenesis by elevating point mutation rate in the somatic genomes (Yin et al., 2006). It was also found that in the liver PCP caused hemodynamic vein changes and injury in the hepatocytes such as cellular swelling and vacuolar degeneration and induced oxidative DNA damage in mouse liver (Villena et al., 1992; Sai-kato et al., 1995). 
Moreover, PCP also induced the transcriptional activity of genes related to the classical apoptosis pathway, oxidative stress, glutathione metabolism and mitogenic response (cyclinD1) in rat neurons (Jaume et al., 2009) which was proved to induce transcriptional up-regulation of stress genes, apoptosis-related genes (p53, Bax and caspase 3), and to down-regulate pro-survival Bcl2 gene (Wang et al., 2000), and repressed IL21 and IL9 expression thus affecting various downstream signaling pathways (Amita et al., 2008).

What is more, exposure to high levels of PCP has been reported to result in increase in body temperature, liver defects, damage to the immune system, disruption of normal sexual, cognitive, physical and emotional development (Proudfoot, 2003). The body temperature can increase to dangerous levels, causing injury to various organs and tissues, and even death. Liver effects and damage to the immune system have also been observed in humans exposed to high levels of PCP for a long time. Previous studies have mostly focused on the single toxicity with respect to these chemicals and there is rarely any report so far about the effect on global protein profiles exposed to PCP.

As an ideal mode animal for toxicological studies, rare minnow (Gobiocypris rarus) has been widely used for aquatic toxicity testing (Zhou et al., 1995; Zha et al., 2007). Belonging to the largest family of Cyprinidae, rare minnows are found predominantly upstream of the Yangtze River, Sichuan Province, China. The fish are small (30-80 $\mathrm{mm}$ in length) and easy to culture in the laboratory. Having relatively short life cycles, spawning hundreds of eggs with high fertilization rates, and hatching rates, rare minnow is a suitable organism in aquatic toxicological tests which has been used in a variety of toxicological assessments of chemicals (Zha et al., 2007; Wei et al., 2007).

Proteomics is an effective platform to globally detect and characterize proteins. Comparative proteomic approach is the main strategy of proteomics to analyze and compare the differentially expressed proteins in toxicological studies (Wetmore and Merrick, 2004; Dowling and Sheehan, 2006). Two-dimensional gel electrophoresis (2-DE) is a powerful proteomic technique to differentially display protein expression.

It is essential to further investigate the toxic effect and mechanisms of PCP on aquatic (rare minnow as a test fish). In the present study, 2-DE was used to analyze the differentially expressed hepatic proteins in rare minnow after PCP exposure, 18 protein spots were identified successfully. These proteins were involved in transport, metabolism, response to oxidative stress and other biological process, which can be used as potential biomarkers for monitoring studies and investigating possible mechanisms of these series of chemicals (Merrick and Bruno, 2004). Furthermore, in order to assay the mRNA expression of these proteins, four differentially expressed mRNA encoding selected proteins (L-FABP, F-1,6-BP, MATPs and GDH) underwent quantitative analysis by quantitative real-time PCR (QRT-PCR). On the basis the proteomic analysis together with the transcriptional data, this work will provide the basis for understanding the potential mechanisms of toxicity of PCP.

\section{Materials and methods}

\subsection{Chemicals}

Pentachlorophenol (PCP) (purity $>99.7 \%$ ) was of analytical grade and purchased from Sigma (CAS No. 131-52-2, Sigma, USA). Pentachlorophenol was dissolved in dimethyl sulfoxide (DMSO). The final DMSO concentration in the water was less than $0.01 \%$.

\subsection{Test fish and exposure experiments}

In the laboratory, rare minnows were raised in flow-through system with de-chlorinated tap water (using active carbon), continuous water filtration with activated charcoal. During breeding, fish were subjected to a 16:8 h of light:dark at a constant temperature $25 \pm 1{ }^{\circ} \mathrm{C}$. After 1 week acclimated period, male and female rare minnows were randomly selected (male:female $=1: 1$, gender determined by observing the shape of the abdomen and the distance between the abdominal fin and the tail fin). Each tank contained 10 male and 10 female rare minnows, and the body weight and body length were $1.5 \pm 0.3 \mathrm{~g}$ and $40-60 \mathrm{~mm}$, respectively.

Adult male and female rare minnows (Gobiocypris rarus) were exposed to different concentrations of PCP at $0,0.5,5,50 \mu \mathrm{g} / \mathrm{L}$ for 28 days. These concentrations were selected based on the literature (Lu and Shen, 2002), the each treatment and control group contained 10 male and 10 female rare minnows in duplicate tanks. Tap water was passed through an active carbon filter, aerated and heated to $26^{\circ} \mathrm{C}$ in a reservoir before it was continuously supplied to each aquarium at a rate of $5 \mathrm{~L} / \mathrm{h}$ and flow rates were checked twice daily. The chemical aquaria kept in stock solutions were dosed independently at $60 \mathrm{~mL} / \mathrm{h}$ by infusion from a 4-L glass aspirator, using a measuring cylinder, the flow rate of the water for dilution was checked daily Aspirators were refilled every second day. The water and the chemicals were mixed and then dispersed to each tank at a rate of $5 \mathrm{~L} / \mathrm{h}$, the control group received dechlorinated tap water and the solvent control group was exposed only to solvent carrier (0.01 mL/L DMSO).

\subsection{Preparation of samples for two-dimensional gel electrophoresis}

The hepatic tissue was ground with liquid nitrogen, and $150 \mu \mathrm{g}$ sample was collected, then mixed with ice-cold lysis buffer $(40 \mathrm{mM}$ Tris, $7.0 \mathrm{M}$ urea, $2.0 \mathrm{M}$ thiourea $4.0 \%$ CHAPS, $1.0 \%$ DTT, $1 \mathrm{mM}$ EDTA. $\mathrm{Na}_{2}$ ) and $20 \mu \mathrm{L}$ protease inhibitor cocktail (PI), which was then placed into an Eppendorf tube and vortexed vigorously on ice for 5 min until all tissues were completely lysed. Precipitation was removed by centrifugation at $14,000 \times g$ at $4{ }^{\circ} \mathrm{C}$ for $20 \mathrm{~min}$, and the supernatants were collected. Protein concentration was determined using the Bradford strictly.

\subsection{Two-dimensional electrophoresis}

First-dimension isoelectric focusing was carried out using Amersham Biosciences Inc., Mulyiphor II system as described by the manufacturer. To isolate the altered proteins more efficiently, the narrow pH 4-7 IPG strips $(18 \mathrm{~cm})$ for the first dimension were used to better separate the total proteins, and the running conditions are: rehydration for $1 \mathrm{~h}, 30 \mathrm{~V}$ for $10 \mathrm{~h}$, step and hold at $500 \mathrm{~V}, 1000 \mathrm{~V}$ for $0.5 \mathrm{~h}$ respectively, and then at $8000 \mathrm{~V}$ until reaching total $80,000 \mathrm{Vhs}$. Then, strips were equilibrated with a solution containing $6 \mathrm{M}$ urea, $30 \%$ glycerol, $2 \% \mathrm{SDS}, 50 \mathrm{mM}$ Tris ( $\mathrm{pH} 8.8$ ) reduced with $100 \mathrm{mM}$ DTT, followed by 15 min in IPG buffer plus $1.0 \%$ iodoacetamide. 2-DE was performed using 13\% isocratic SDS-PAGE gels. The electrophoresis was performed at $20 \mathrm{~V}$ for $40 \mathrm{~min}$ and then at $30 \mathrm{~V}$ until bromopheno blue front reached the end of the gel (Ettan Dalt, GE Healthcare). The gels were then visualized by silver staining and Coomassie Brilliant Blue G-250 staining for image analysis and select spot respectively. For a reliable analysis of protein expression, 2-DE of each gels was performed in triplicate.

\subsection{Image analysis}

Sliver staining was selected for image analysis in this study on account of its more sensitivity for spot detection as compared to Coomassie Brilliant Blue G-250 staining. Image analysis was performed using ImageMaster software (Amersham Biosciences) according to the protocols provided by the manufacturer. All values are expressed as the mean $\pm S D$, and the difference on the abundance of protein spot was analyzed with a two-tailed $t$-test. The level of significance was set at $p<0.05$.

\subsection{Protein identification}

The separated proteins in SDS-PAGE gels were visualized by Coomassie Brilliant Blue G-250 staining. Selected differential expression protein spots were excised from preparative gels and in-gel digestion was performed. The gel-spots were washed three times with two-distillation water and destained with the fresh solution containing $100 \mathrm{mM} \mathrm{NH}_{4} \mathrm{HCO}_{3}$ in $50 \%$ acetonitrile at $37^{\circ} \mathrm{C}$. After dried in a vacuum centrifuge, the gel-pieces were incubated in $10 \mu \mathrm{L}$ digestion solution that consisted of $40 \mathrm{mM} \mathrm{NH}_{4} \mathrm{HCO}_{3}$ in $9 \%$ acetonitrile solution, and $20 \mu \mathrm{g} / \mathrm{mL}$ proteomic grade trypsin (Promega, USA) for $10-12 \mathrm{~h}$ at $37^{\circ} \mathrm{C}$.

The standard peptide mixture was spotted at the same time to correct the machine. In peptide mass fingerprint (PMF) map database searching, Mascot Distiller was used to get the monoisotopic peak list from the raw mass spectrometry files. Peptide matching and protein searches against the NCBI nonredundant (nr) databases were performed using Mascot search engine (http://www.matrixscience.com) with a mass tolerance of $\pm 0.3 \mathrm{Da}$. One missed coverage site was allowed for trypsin digestion, cysteine carbamidomethylation was assumed as a fixed modification, iodoacetamide as the modification for cysteine and methionine oxidation as a variable modification. Proteins were considered as identified only when they had a protein score greater than 82 , results with C.I.\% (confidence interval\%) values $>95 \%$ were considered to be a positive identification. The identified proteins were then matched to specific biological processes or functions by searching gene ontology using Uniprot/Swissprot database and submitted to ingenuity. 
Table 1

Gene-specific primers used in quantitative real-time PCR.

\begin{tabular}{|c|c|c|c|}
\hline Gene & Forward primer & Reverse primer & Product size (bp) \\
\hline$\beta$-Actin & GCC GTG ACC TGA CTG ACT AC & GCA AGA TTC CAT ACC CAA GA & 284 \\
\hline L-FABP & TTC CTT CTC CAA GCG GTC TA & TGA AGT CGT TGC CGT TTT GT & 240 \\
\hline GDH & ACA GTG AAG TCG TGG GAA AT & GGA GAA GAT GGG TAA AGG GT & 100 \\
\hline F-1,6-BP & CTT GTG GAT CGG GAT GTG AGG & CTT GCC CTT GGG ACT CTT GAC & 240 \\
\hline MATPS & CAG TAC CTG GCT CCA TAC T & GGT GGG AAT GTA AGC GGA C & 294 \\
\hline
\end{tabular}

\subsection{Quantitative real-time PCR (QRT-PCR)}

The four differentially expressed proteins were examined to detect the corresponding mRNA levels by quantitative real-time PCR. The detected genes included: liver-basic fatty acid-binding protein (L-FABP), glutathione peroxidase (GDH), mitochondrial ATP synthase (MATPs) and fructose-1,6-bisphosphatase (F-1,6-BP). Gene names, forward and reverse primer sequences and product length are listed in Table 1. PCR amplification was performed using SYBR Green PCR Master Mix reagent kits on ABI Prism 7300 QRT-PCR system (USA). Every sample was analyzed individually and processed in triplicate. The housekeeping gene $\beta$-actin was used as an internal control to normalize the data. One-way analysis of variance (ANOVA) was used for statistical analysis between the PCP-exposed groups and the control. Differences were considered significant when $p$-values were $<0.05$.

\subsection{Statistical analysis}

Data were analyzed using SPSS for Windows 13.0 (SPSS Inc., Chicago, IL, USA) and presented as mean with standard error (mean \pm S.E.M.). The expression levels of genes and proteins between the control and treatment groups were analyzed by

\section{Female}
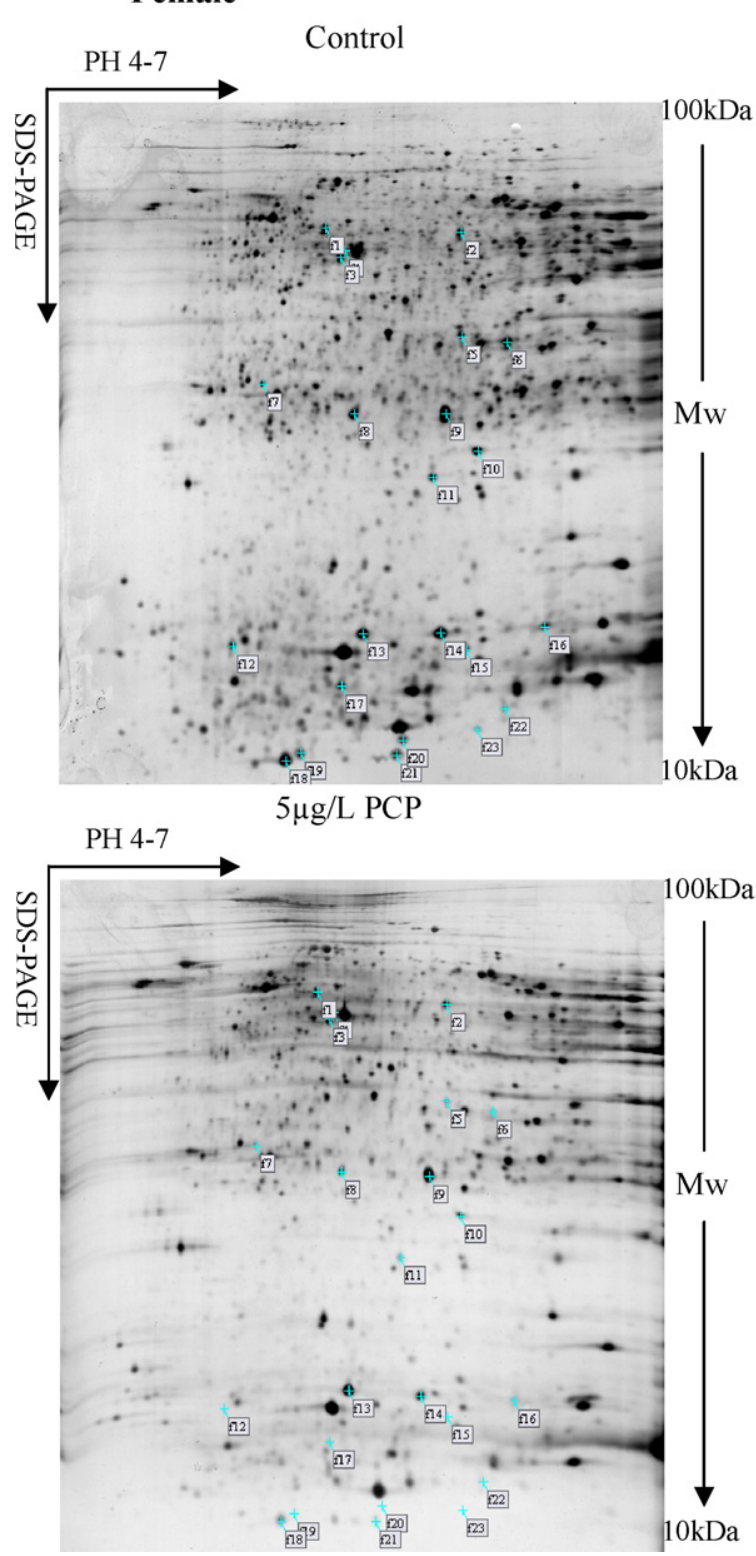

Male
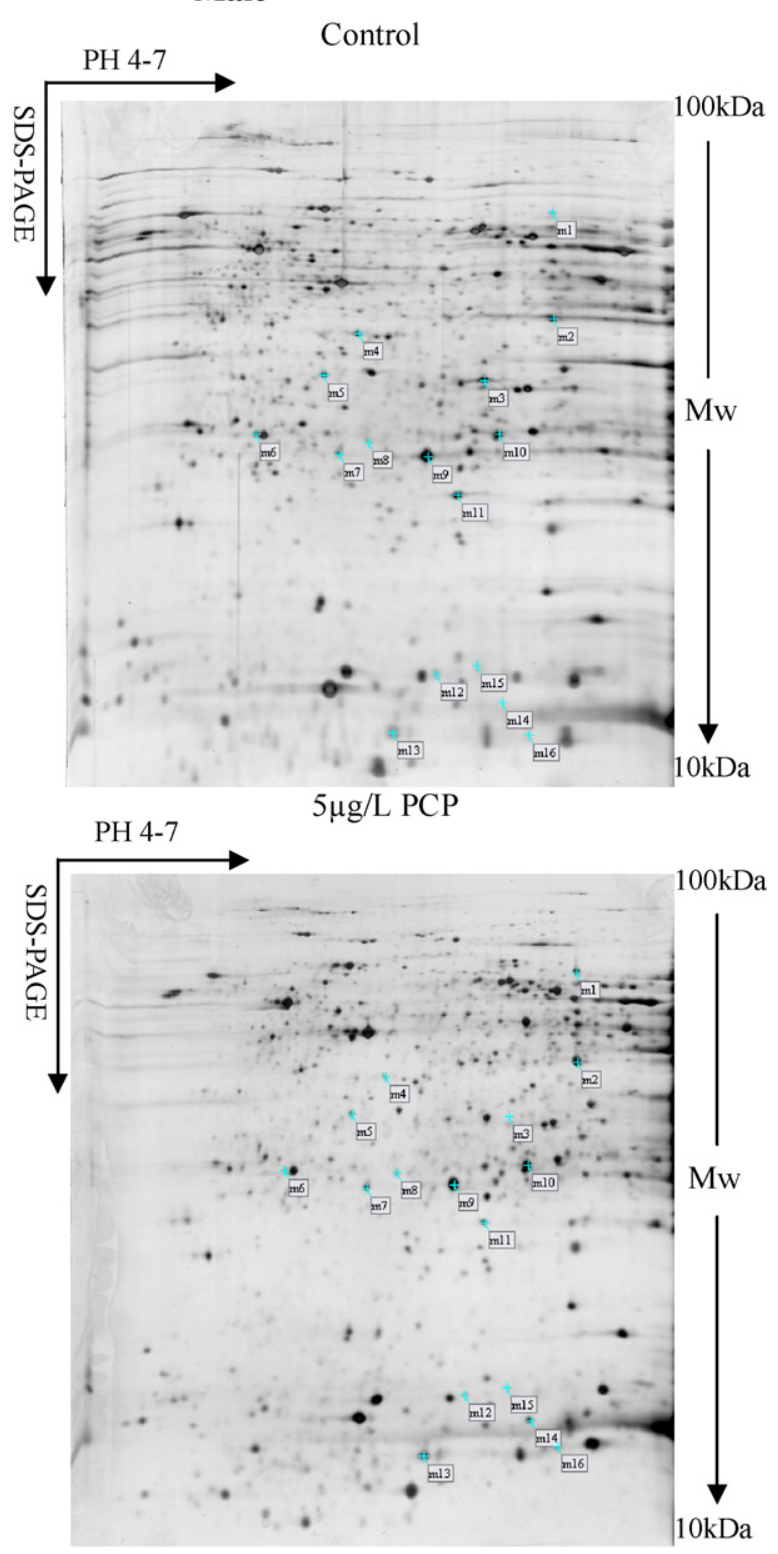

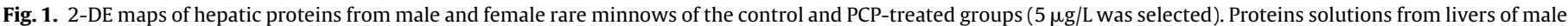

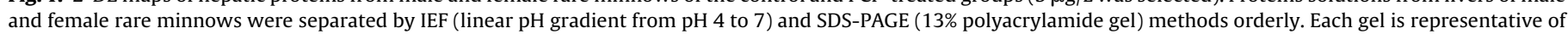
three independent replicates. 

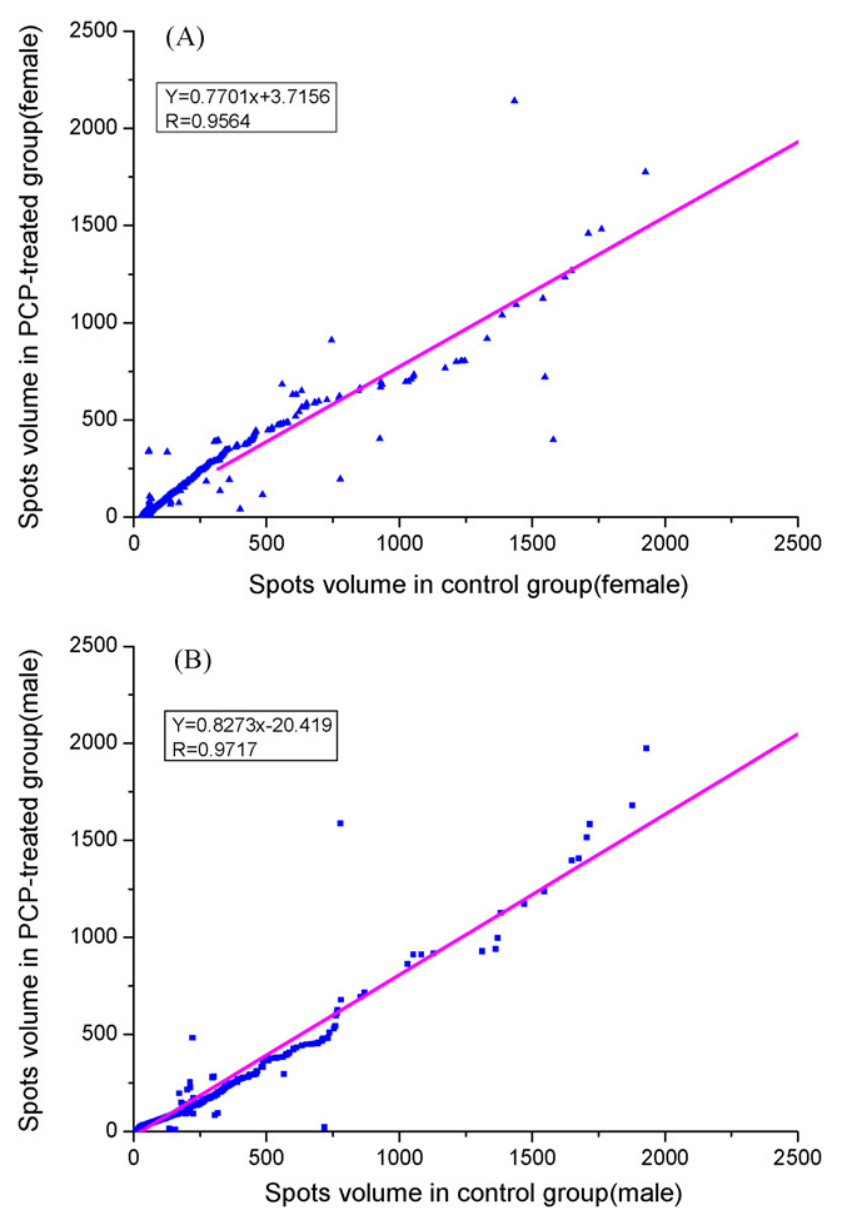

Fig. 2. Characterization of global protein expression in male and female images: (A) the number of spots in normal male and female images; (B) scattergram depiction of 2-D data to generate protein expression profile (male sample), $Y=0.82727 x-20.419, R=0.97174$ and (C) scattergram depiction of 2-D data to generate protein expression profile (female sample), $Y=0.77174 x+3.71562$, $R=0.95643$.

one-way ANOVA followed by Dunnett's post hoc two-sided $t$-test. Values of $p<0.05$ were considered as statistically significant.

\section{Results}

\subsection{D gel analysis of differentially expressed proteins}

In our present study, we performed 2-DE to describe the hepatic protein profiles of rare minnows following PCP exposure, and quantitative spot comparisons were made with Image Master 2D Platinum software (Amersham Biosciences). Considering the possible gender differences in the response of organisms to PCP, the male and female samples were analyzed separately, for each sample $150 \mu \mathrm{g}$ protein was prepared for first-dimension isolectric by manufacturer, protein concentration was determined by Bradford method strictly. The reference gel images from the control and $5 \mu \mathrm{g} / \mathrm{L}$ PCP-treated groups with silver stain are shown in Fig. 1. Results showed that: there were approximately 1000 spots were detected in normal female image, while 800 spots in normal male image, this might caused by female fish play an important role in reproduction and other functions which were not related to male ones. Moreover, compared with gel from control group, the abundance of global protein spots of PCP-treated groups represent difference, the extent of variety following PCP exposure in male was bigger than that in female sample, which were denoted by slope (Fig. 2A and B), slope $<1$ indicate that the abundance of proteins at PCP-treated groups were diminuted. Slopes in male and female groups display the significant change ( 0.8273 in male group and 0.7701 in female group), which suggests that the effect of male fish induced by PCP-treament was significant than that of female fish and it can be concluded that gender differences are in the response of organisms to PCP. Image analysis revealed that 39 spots were found to be altered in abundance ( $>2$-fold) from male and female PCP-treated groups, 23 spots in female protein sample, and 16 spots in male sample respectively, the altered protein spots with sliver stain were selected and labeled by f/m and No. (Fig. 1).

\subsection{Identification of differential expression proteins by MALDI-TOF-MS and MALDI-TOF/TOF-MS}

39 differentially expressed protein spots (marked with the number square bracket) were in situ digested with trypsin and analyzed by MALDI-TOF and MALDI-TOF/TOF and searched using Mascot search engine, 18 protein spots were successfully identified, among of these, 12 proteins in females and 6 proteins in males. The matched proteins in the database were mainly from Danio rerio, the remaining 21 protein spots could not be identified mainly because their abundance was too low to produce a spectrum, or for the C.I.\% of the database search score was not higher for 95\%. Analysis of the protein expression using Image Master 2D Platinum software provided 3D simulation of the protein spots, allowing an objective view for the comparison of spot intensity between the two images, so, the 3D simulation of four representative spots provides the basis for comparison of protein expression between PCP-treated group and control group (Fig. 3). High-quality PMF, the MALDI-TOF/TOF mass spectrometry map and database query as a result of a representative spot $\mathrm{f} 18$ are shown in Fig. $4 \mathrm{~A}$ and B, respectively.

\subsection{The identified differentially expressed proteins of diverse functional categories}

The identified proteins were then matched to specific biological processes or functions by searching Gene Ontology (GO Terms) using Uniprot/Swissprot database and submitted to ingenuity. We classified those proteins manually to a variety of cellular biological processes, according to that they took part in a variety of cellular biological processes, such as transport, metabolism of lipid, response to oxidative stress, protein repair, oxidative phosphorylation and other related processes (Table 2).

\subsection{Quantitative real-time PCR analysis}

Four genes were accomplished by quantitative PCR analysis across all treatment groups (L-FABP, F-1,6-BP, MATPs and GDH) (Fig. 5). L-FABP expression was significantly decreased at all doses of PCP exposure, but a variety of female groups were almost downregulated at 10 times compared with control group, which was more than 2 times than male groups. Conversely, F-1,6-BP mRNA levels were significantly increased by PCP at all doses $(p<0.05)$. MATPs mRNA levels was increased at the groups of $0.5 \mu \mathrm{g} / \mathrm{L}$ and $5 \mu \mathrm{g} / \mathrm{L}$, but markedly decreased at group of $50 \mu \mathrm{g} / \mathrm{L}(p<0.05)$. The mRNA expression of GDH was increased at $0.5 \mu \mathrm{g} / \mathrm{L}$ and $5 \mu \mathrm{g} / \mathrm{L}$ PCP-treated groups, but reduced at $50 \mu \mathrm{g} / \mathrm{L}$ PCP exposure.

\section{Discussion}

\subsection{Proteins related to transport}

We successfully identified three differential proteins involved in transport, such as the steroid sulfotransferase-like protein (spot f17), liver-basic fatty acid-binding protein b (spot f18), mitochondrial ATP synthase beta subunit-like (spot f1) and mitochondrial 
A. ATP Synthase (f11)
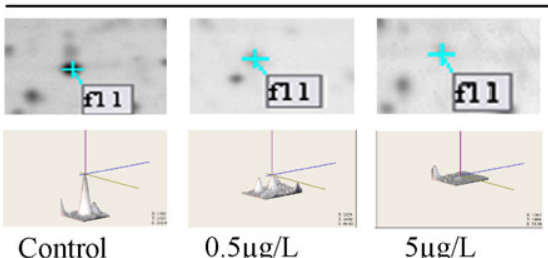

$5 \mu \mathrm{g} / \mathrm{L}$

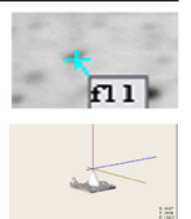

$50 \mu \mathrm{g} / \mathrm{L}$
B. Sarcosine Oxidase (f6)
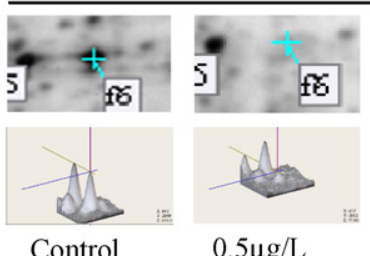

$0.5 \mu \mathrm{g} / \mathrm{L}$

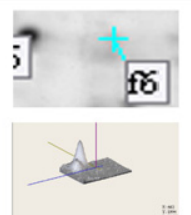

$5 \mu \mathrm{g} / \mathrm{L}$

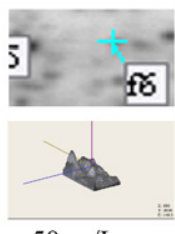

$50 \mu \mathrm{g} / \mathrm{L}$

C. NK cell enhancement factor (f10)

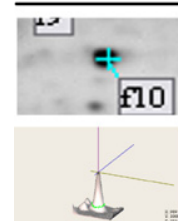

Control

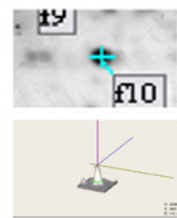

$0.5 \mu \mathrm{g} / \mathrm{L}$

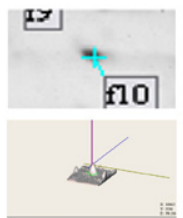

$5 \mu \mathrm{g} / \mathrm{L}$

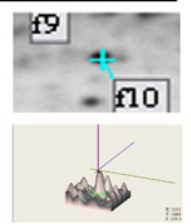

$50 \mu \mathrm{g} / \mathrm{L}$

D. Peptidyl Arginine Deiminase (f7)

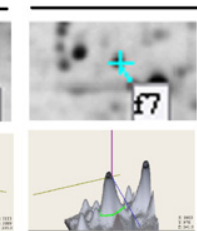

Control

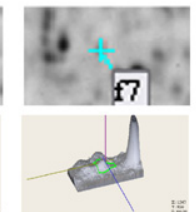

$0.5 \mu \mathrm{g} / \mathrm{L}$

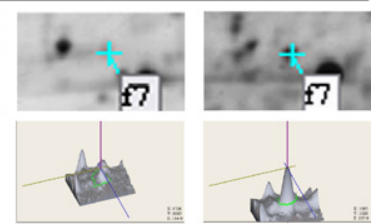

$5 \mu \mathrm{g} / \mathrm{L}$

$50 \mu \mathrm{g} / \mathrm{L}$

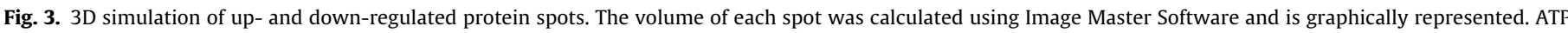
synthase (A), sarcosine oxidase (B), NK cell enhancement factor (C) and peptidyl arginine deiminase (D).

ATP synthase, F1 complex (spot f11). Among these, the mitochondrial ATP synthase beta subunit-like and mitochondrial ATP synthase, F1 complex were two subunit of mitochondrial ATP synthase which were identified from two spots. The altered expressions of proteins suggest that involving in energy transport, sulfonation reactions and fatty acid transport were induced by PCP treatment in liver of rare minnow, which might induce further liver damage.

The expressions of proteins related to transport such as mitochondrial ATP synthase beta subunit-like and mitochondrial ATP synthase, F1 complexes were both depressed in PCP-treated groups (Table 2). ATP synthase is a key component of mitochondrial energy conversion in the mammalian organism as it produces most of the cellular ATP in aerobic cells. This protein complex uses a proton gradient and the associated membrane potential to synthesize ATP. In the previous studies, it suggest that PCP acts primarily by uncoupling substrate oxidation from ATP synthesis in the mitochondria, it converts the potential energy generated with in the electrontransport system into heat instead of ATP, which causes substrate oxidation, uninhibited by respiratory control, as a result, exposed to PCP commonly exhibit increases in oxygen consumption and reductions in stored lipids and growth (Hanstein, 1976; Julie et al., 2001), which indicate that ATP production was decreased and ROS production was increased after PCP-treated. In our present study, mitochondrial ATP synthase beta subunit-like (spot f1) was reduced in $50 \mu \mathrm{g} / \mathrm{L}$ female sample (-4.27-fold, $\geq 2$-fold) (Table 2 ) compared to control group, mitochondrial ATP synthase mRNA levels were increased at the groups of $0.5 \mu \mathrm{g} / \mathrm{L}$ and $5 \mu \mathrm{g} / \mathrm{L}$, but markedly decreased at the group of $50 \mu \mathrm{g} / \mathrm{L}(p<0.05)$. This result further demonstrates that MATPs may play an important role in the liver after PCP treated, which was complied with the above results. No wonder that pronounced defects of this enzyme result in mitochondrial diseases. The decrease of ATP products would disrupt the cellular energy generation, and diminished use of mitochondrial $\Delta \mu \mathrm{H}+$, while promoted the reactive oxygen species (ROS) production by the mitochondrial respiratory chain after PCP exposure (Josef et al., 2006). As a key component of mitochondrial energy conversion, reduce of MATPs in liver may induce mitochondrial diseases and oxidation stress damage in rare minnows. So, we highlight suggest that ATP synthesis might be a biomarker in fish following PCP-treated.

Sulfonation has involved as a key step in xenobiotic metabolism, sulfonation reactions are catalyzed by sulfotransferase (SULT) enzymes (Wang and Margaret, 2007), which plays a critical role in modulating the biological activity and facilitating the inactivation and elimination of potent endogenous chemicals including steroids, thyroid hormones and catechols (Coughtrie, 1996; Falany, 1991; Strott, 2005). Sulfonation of E2 has been reported in human liver, carp and zebrafish (Thibaut and Porte, 2004; Ohkimoto et al., 2004; Jurgella et al., 2006). There is evidence that xenobiotics found in polluted environments can inhibit the phase II conjugating enzymes in fish, including those that catalyze sulfonation and glucuronidation of steroids, and potentially disrupt steroid hormone homeostasis (Wang and James, 2006). In our current study, we detected that SULT (spot f17) exhibited the low abundance in male liver but high abundance in female liver, by compared with the gels from PCP-treated male fish with the control group. Results confirmed that PCP on SULT in liver of female rare minnow express suppressive effects, which might make a potential role in interfering with the sulfonation of endogenous estrogens as well as the hydroxylated metabolites of polychlorinated biphenyls (OH-PCBs) (Hurk et al., 2002). However, the expression of SULT in female and male liver were different after PCP treated, this result might because there have SULT in normal liver of female, of which play a key enzyme of sulfonation. PCP induced SULT upregulation in female but down-regulation in male, which indicated that marked gender differences of SULT's expression in response to PCP in rare minnows. However, the cause of the discrepancy of alteration in different gender of SULT by PCP need further investigation, nevertheless, the results in our present study suggest that the SULT might be regarded as candidate biomarker for PCP exposure.

Fatty acid-binding proteins (FABPs) are members of the superfamily of lipid-binding proteins (LBP), comprise a family of 14-15 kDa cytosolic protein which bind long-chain fatty acids (Judith et al., 2000). The primary role of all the FABP family members is regulation of fatty acid uptake and intracellular transport. Liver fatty acid-binding protein (L-FABP) is expressed in a declining gradient between the portal and central zones of the liver acinus (Bass, 1990), which are small cytosolic proteins that facilitate the solubility and intracellular transport of fatty acids (Zimmerman et al., 2001). In present study, we demonstrate that the expression of L-FABP was marked suppressed in female fish under treatments of $5 \mu \mathrm{g} / \mathrm{L} \mathrm{PCP}$ (-7.97-fold) (Table 2 ). On the basis of the result by QRT-PCR, L-FABP mRNA was down-regulated. This result implies PCP may interfere with the binding of fatty acids or other endoge- 
(A)

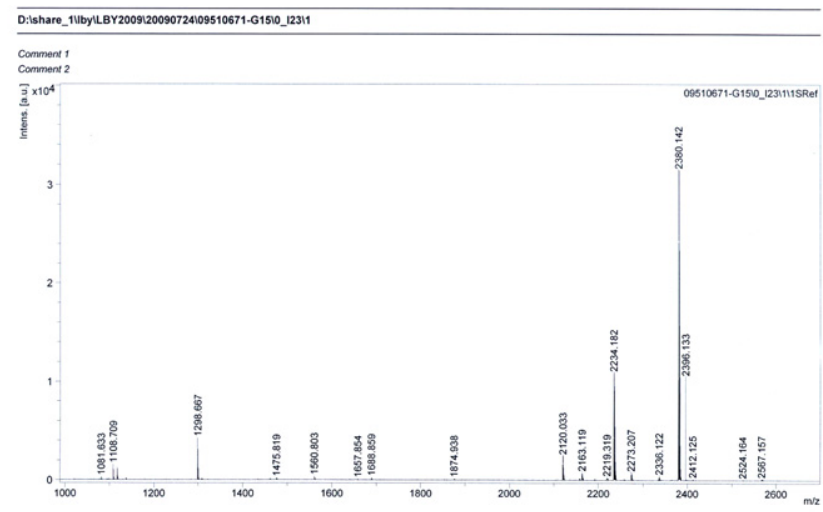

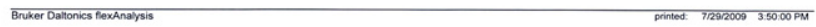

\section{MAFRGTWQVY VQENYEEFLR AISLPEDVIK MAKDVKPVTE IQQNGNDFTI $\mathbf{5 1}$ TSK TPGKTVT NSFTIGKEAE ITTMDGKKLK CIVKLEGGKL VCOTDRFSHI 101 QEIK GGEMVE TLTVGGTTMI RRSKKM}

(B)

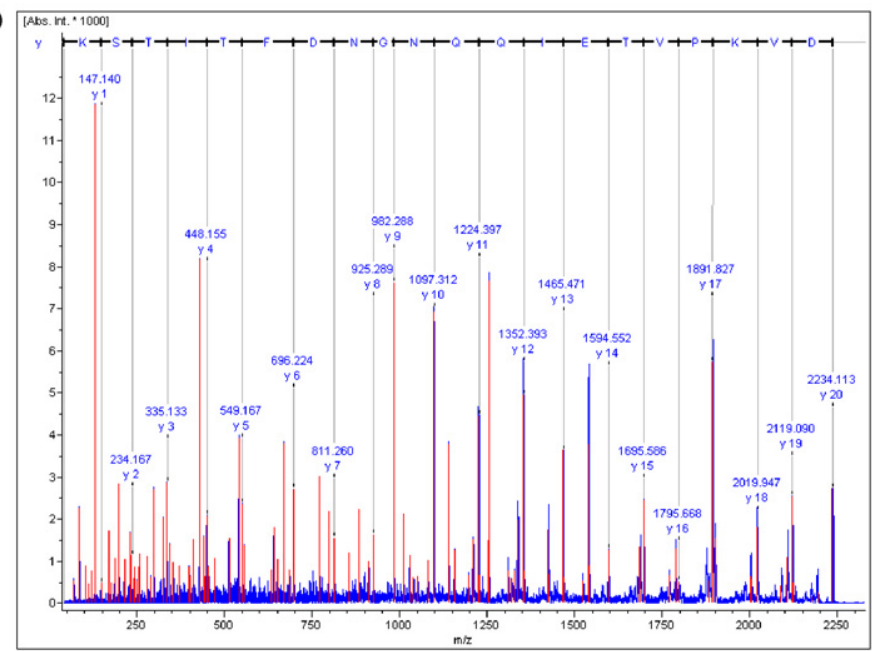

\section{MAFRGTWQVY VQENYEEFLR AISLPEDVIK MAKDVKPVTE IOQNGNDFTI 51 TSKTPGKTVT NSFTIGKEAE ITTMDGKKLK CIVKLEGGKL VCQTDRFSHI 101 QEIKGGEMVE TLTVGGTTMI RRSKKM}

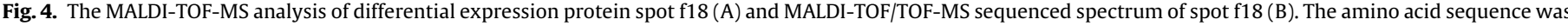

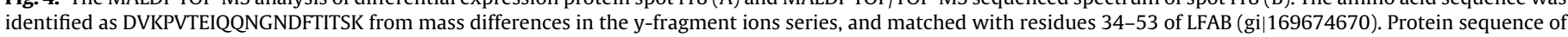
LFAB is shown, and matched MS/MS fragmentation is underlined.

nous ligands to L-FABP and displacement of endogenous ligands from L-FABP (Luebker et al., 2002), the suppressive effects of PCP on L-FABP which may be implicated in the perturbation of fatty acid transport in the liver. Furthermore, L-FABP is involved in the physiological regulation of cholesterol metabolism, body weight gain, and obesity (Gregory et al., 2006). Our results suggest that, down-regulated of L-FABP might affect cholesterol metabolic disturbance, lost of weight and obesity, and than lower resistance of rare minnow.

\subsection{Proteins related to metabolism}

The expression level of some metabolic enzymes had obvious changes in PCP-treated group, such as: sarcosine oxidase, glutamate dehydrogenase (GDH) and fructose-1,6-bisphosphatase. Among of these proteins, sarcosine oxidase (spots f6, m3) were detected down-regulator in female and male rare minnow (Fig. 3B), glutamate dehydrogenase (spot m6) and fructose-1,6- bisphosphatase (spot $\mathrm{m} 2$ ) were also detected down-regulator in male fish. These results suggested that an apparent effect of metabolism induced by exposure of PCP in rare minnow.

Sarcosine oxidase is a heterotetrameric (alpha, beta, gamma, delta) enzyme, which containing covalent and noncovalent FAD, catalyzes the oxidative demethylation of sarcosine to yield glycine, $\mathrm{H}_{2} \mathrm{O}_{2}$, and $5,10-\mathrm{CH}_{2}$-tetrahydrofolate $\left(\mathrm{H}_{4}\right.$ folate) in a reaction requiring $\mathrm{H}_{4}$ folate and $\mathrm{O}_{2}$ (Chlumsky et al., 1995). The gammasubunit is similar to the C-terminal sub-domain of alpha-TSOX (Chen et al., 2006). Although the function of gamma-subunit so far was not clear, our present study showed that, the abundance of sarcosine oxidase was almost disappear in female liver and marked down-regulated in male liver after PCP treated, which would reduce the products of glycine and $5,10-\mathrm{CH}_{2}$-tetrahydrofolate by oxidative demethylation of sarcosine undoubtedly. As a key component nonessential amino acids, glycine was basic unit of protein and precursor of glucose, fatty acids and acetone body. The reduction of product of glycine would affect the form of protein and energy 
Table 2

A detailed list of protein spots identified by MALDI-TOF/TOF-MS from the livers of female rare minnows following PCP treatment (score C.I. >95\%).

\begin{tabular}{|c|c|c|c|c|c|c|c|c|c|c|}
\hline \multirow{2}{*}{$\begin{array}{l}\text { No. on gel } \\
1\end{array}$} & \multirow[t]{2}{*}{ Protein name } & \multirow[t]{2}{*}{ Species } & \multirow[t]{2}{*}{ Accession no. } & \multirow[t]{2}{*}{ Protein score } & \multirow[t]{2}{*}{ Theorectical $\operatorname{Mr}(\mathrm{Da}) / \mathrm{p} I$} & \multirow[t]{2}{*}{ Experimental $\mathrm{Mr}(\mathrm{Da}) / \mathrm{p} I$} & \multicolumn{3}{|c|}{$\begin{array}{l}\text { Fold change (treated } \\
\text { with control) }\end{array}$} & \multirow[t]{2}{*}{ Functional category } \\
\hline & & & & & & & 0.5 & 5 & 50 & \\
\hline \multicolumn{11}{|l|}{ Transport } \\
\hline f1 & $\begin{array}{l}\text { Mitochondrial ATP } \\
\text { synthase beta subunit-like }\end{array}$ & Danio rerio & 66773080 & 146 & $54,966 / 4.93$ & $48,450 / 5.24$ & -3.20 & -1.91 & -4.27 & $\begin{array}{l}\text { ATP synthesis/hydrogen } \\
\text { ion transport/ion } \\
\text { transport/transport }\end{array}$ \\
\hline $\mathrm{f} 11$ & $\begin{array}{l}\text { ATP synthase, } \mathrm{H}^{+} \\
\text {transporting, } \\
\text { mitochondrial } \mathrm{F} 1 \text { complex }\end{array}$ & Danio rerio & 116325975 & 157 & $34,671 / 6.42$ & $33,383 / 5.74$ & -9.56 & - & -31.25 & $\begin{array}{l}\text { ATP synthesis coupled } \\
\text { proton transport }\end{array}$ \\
\hline f15 & Gastrotropin & Salmo salar & 209734398 & 90 & $14,219 / 4.90$ & $15,008 / 5.34$ & - & - & - & Transport \\
\hline f17 & $\begin{array}{l}\text { Steroid } \\
\text { sulfotransferase-like } \\
\text { protein }\end{array}$ & Arabidopsis thaliana & 9759557 & 87 & $36,285 / 8.02$ & $13,661 / 5.32$ & - & - & -71.63 & Transferase \\
\hline f18 & $\begin{array}{l}\text { Liver-basic fatty } \\
\text { acid-binding protein } \mathrm{b}\end{array}$ & Cyprinus carpio & 169674670 & 138 & $14,150 / 8.89$ & $11,263 / 5.06$ & -1.61 & -7.97 & -1.31 & Transport \\
\hline \multicolumn{11}{|c|}{ Metabolism } \\
\hline f6 & $\begin{array}{l}\text { Sarcosine oxidase, gamma } \\
\text { subunit }\end{array}$ & Rhodobacterales bacterium HTCC2083 & 254461420 & 84 & $17,313 / 9.20$ & $33,677 / 6.09$ & - & - & - & $\begin{array}{l}\text { Glycine } \\
\text { catabolic/tetrahydrofolate } \\
\text { metabolic process }\end{array}$ \\
\hline $\mathrm{m} 3$ & $\begin{array}{l}\text { Sarcosine oxidase, gamma } \\
\text { subunit }\end{array}$ & Rhodobacterales bacterium HTCC2083 & 254461420 & 84 & $17,313 / 9.20$ & $33,973 / 6.09$ & -2.31 & -2.98 & -3.45 & $\begin{array}{l}\text { Glycine } \\
\text { catabolic/tetrahydrofolate } \\
\text { metabolic process }\end{array}$ \\
\hline $\mathrm{m} 2$ & $\begin{array}{l}\text { Fructose-1,6- } \\
\text { bisphosphatase } \\
\text { 1b }\end{array}$ & Danio rerio & 47085885 & 146 & $36,805 / 6.90$ & $40,405 / 6.38$ & 2.44 & 4.51 & 4.66 & Carbohydrate metabolism \\
\hline $\mathrm{m} 6$ & Glutamate dehydrogenase & Aedes aegypti & 157138024 & 84 & $58,585 / 9.06$ & $29,937 / 4.91$ & - & -0.16 & 2.34 & $\begin{array}{l}\text { Cellular amino acid } \\
\text { metabolic } \\
\text { process/oxidation } \\
\text { reduction }\end{array}$ \\
\hline \multicolumn{11}{|c|}{$\begin{array}{l}\text { Responses to } \\
\text { oxidative stress }\end{array}$} \\
\hline f10 & $\begin{array}{l}\text { Natural killer cell } \\
\text { enhancement factor }\end{array}$ & Cyprinus carpio & 84569882 & 111 & $21,857 / 5.93$ & $23,623 / 5.94$ & -1.15 & -4.26 & -2.90 & Cell redox homeostasis \\
\hline $\mathrm{m} 11$ & $\begin{array}{l}\text { Natural killer cell } \\
\text { enhancement factor }\end{array}$ & Cyprinus carpio & 84569882 & 111 & $21,857 / 5.93$ & $23,623 / 5.94$ & 0.87 & 0.23 & 0.35 & Cell redox homeostasis \\
\hline $\mathrm{m} 15$ & $\begin{array}{l}\text { Methionine sulfoxide } \\
\text { reductase B }\end{array}$ & Danio rerio & 90422991 & 261 & $20.38 / 7.63$ & $19,543 / 7.11$ & 1.43 & 4.43 & - & $\begin{array}{l}\text { Protein repair/response to } \\
\text { oxidative stress }\end{array}$ \\
\hline \multicolumn{11}{|c|}{$\begin{array}{l}\text { Other function } \\
\text { related }\end{array}$} \\
\hline f2 & Keratin 18 & Danio rerio & 30410758 & 180 & $48,631 / 5.53$ & $47,466 / 5.87$ & -2.03 & -4.58 & -7.81 & Intermediate filament \\
\hline f4 & $\beta$-actin protein & Danio rerio & 28279111 & 210 & $41,767 / 5.30$ & $43,773 / 5.39$ & 1.24 & 1.08 & 1.02 & Cytoplasm cytoskeleton \\
\hline \multirow[t]{2}{*}{ f7 } & $\begin{array}{l}\text { Peptidyl arginine } \\
\text { deiminase, type II }\end{array}$ & Danio rerio & 41056223 & 85 & $72843 / 9.21$ & & & & & \\
\hline & $29,738 / 4.95$ & -4.74 & -3.21 & -1.12 & Transposition, DNA-mediated & & & & & \\
\hline f16 & $\begin{array}{l}\text { Fhu operon transcription } \\
\text { regulator }\end{array}$ & Oenococcus oeni PSU-1 & 116491070 & 76 & $35,229 / 8.92$ & $16,692 / 6.18$ & - & -7.57 & 2.36 & $\begin{array}{l}\text { Transcription/transcription } \\
\text { regulation }\end{array}$ \\
\hline $\mathrm{f} 21$ & $\begin{array}{l}\text { Similar to gag-pol fusion } \\
\text { polyprotein, partial }\end{array}$ & Danio rerio & 189526528 & 74 & $19,7521 /-$ & $11,437 / 5.57$ & -9.47 & - & -7.97 & Ployprotein process \\
\hline $\mathrm{m} 12$ & $\begin{array}{l}\text { Fatty acid-binding protein } \\
\text { H6 }\end{array}$ & Rutilus rutilus & 219665281 & 89 & $13,191 / 6.53$ & $16,146 / 5.89$ & 2.14 & 1.13 & 2.66 & Transport \\
\hline
\end{tabular}

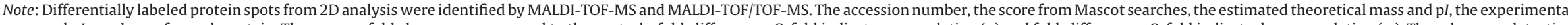

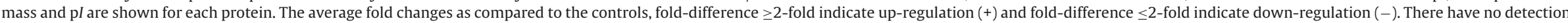
protein spots in gels are noted by "-". Functional category according to biology processes in GO term. 

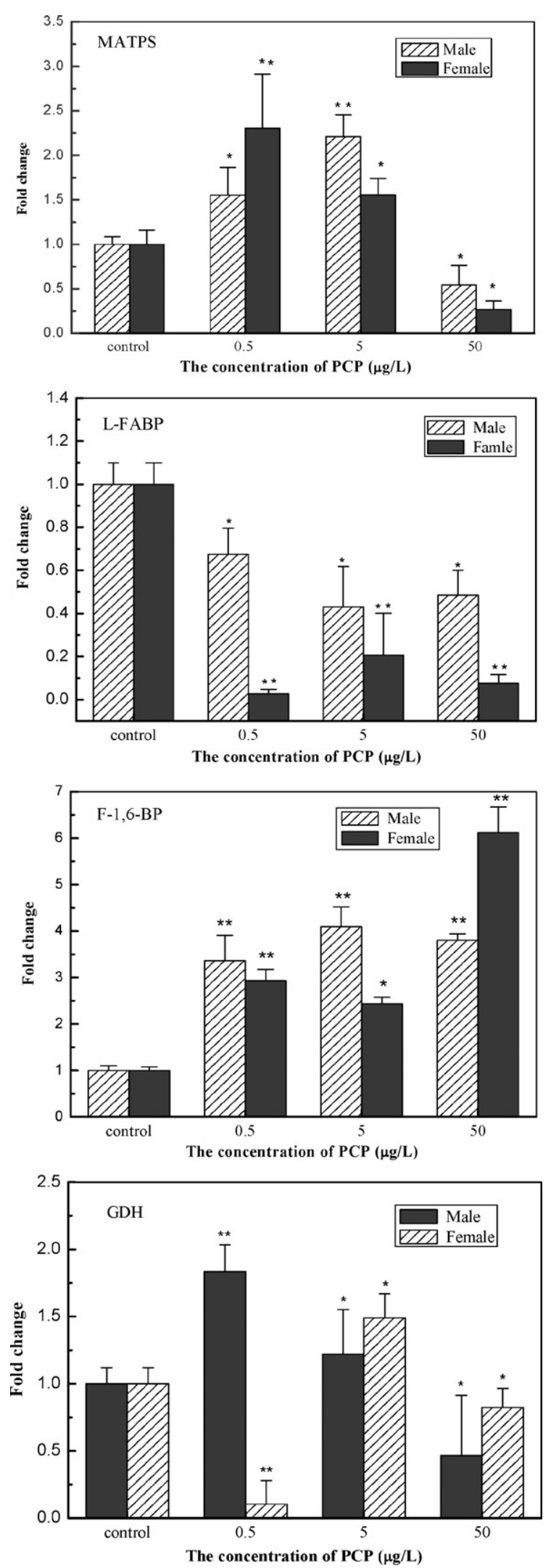

Fig. 5. Real-time PCR analysis of selected genes. Abbreviations: MATPs, mitochondrial ATP synthase; L-FABP, liver-basic fatty acid-binding protein; F-1,6-BP, fructose-1,6-bisphosphatase; GDH, glutathione peroxidase. Bars represent the relative fold changes compared with controls. Error bars represent the S.E.M. for the average fold changes. Statistical significance $(p<0.05)$ between expression following PCP exposure and the controls is denoted by an asterisk $\left({ }^{*}\right)$. metabolism. Results suggest that PCP reduced the product of sarcosine oxidase and than reduce that of glycine.

Glutamate dehydrogenase (GDH) catalyzes the oxidative deamination of glutamate to alpha-ketoglutarate using NAD or NADP as cofactors (Plaitakis and Zaganas, 2001), of which is a mitochondrial matrix enzyme that is expressed in high levels only in liver, B-cells, brain, and kidney (Charles, 2004). In present study, the abundance of GDH were down-regulated dramatically in female liver following $0.5 \mu \mathrm{g} / \mathrm{L}, 5 \mu \mathrm{g} / \mathrm{L}$ PCP exposure, PCP could disrupt oxidative deamination, and further induce the product of alphaketoglutarate. These results indicate that PCP induced significant reductions of alpha-ketoglutarate, and than the product of glucose might be grow in number by gluconeogenesis. In present study, we demonstrate that ATP synthase converts the potential energy into heat instead of ATP lead to the lack of ATP, but the increase of GDH capable complement the product of ATP. After $50 \mu \mathrm{g} / \mathrm{L}$ PCP exposure, up-regulate was observed in female, this might be demonstrated that, high-dose PCP could induce GDH expression or other pathway which capably produce a mount of GDH. This might be the pathway of energy of rare minnows by PCP treated. Furthermore, the mechanisms of the effects need further studies. GDH mRNA levels were increased at the groups of $0.5 \mu \mathrm{g} / \mathrm{L}$ and $5 \mu \mathrm{g} / \mathrm{L}$, but markedly decreased at the group of $50 \mu \mathrm{g} / \mathrm{L}(p<0.05)$ (Fig. 6). This result showed different trends of proteins in male fish, the relationship between transcription of mRNA and the abundance of protein is not always a direct one as there are many regulatory mechanisms that can affect these processes (Wei et al., 2007).

\subsection{Proteins related to oxidative stress}

Two proteins associated with oxidative stress were observed to alter in male and female fish following PCP-treament. Natural killer cell enhancement factor (NKEF) was down-regulation both in male and female fish compared with control. Methionine sulfoxide reductase (MSR) was up-regulation in male fish but no alteration in the female one (Table 1). Previous studies have shown that PCP toxicity seems to be related to the uncoupling of oxidative phosphorylation in mitochondria, and the generation of ROS would be the principal mechanism of action (Proudfoot, 2003), which could elicit the elevation of enzymatic activities of a variety of antioxidant enzymes, such as catalase (CAT), superoxide dismutase (SOD), and glutathione reductase (Zhang et al., 2008).

Natural killer cell enhancement factor (NKEF) belongs to the antioxidant protein family. In the humans, NKEF has the ability to enhance natural killer cell cytotoxic activity in vitro, but the cDNA and amino acid sequences of trout NKEF have high similarity with human, rat, mouse and carp sequences, therefore, indicating that NKEF is a conserved gene (Zhang et al., 2001). Natural killer (NK) cells can mediate numerous anti-tumor and anti-viral effector functions as well as play important immunoregulatory roles in various disease states (William et al., 2006). In the present study, the expression of NKEF (spots f10, m11) was reduced in male and female after $5 \mu \mathrm{g} / \mathrm{L}$ PCP exposure (Fig. 3C), which indicated PCP might induce tumor and viral disease by elevating immunoregulatory effect in fish following exposure to PCP. These results were accorded with the results that the PCP was likely to promote tumor (Kimie et al., 2001), but different from a previous report that pentachlorophenol-induced apoptosis in rat neurons (Jaume et al., 2009). This might be caused by the difference of cell/tissue specificities.

Methionine sulfoxide reductase (MSR) is an enzyme which can reduce methionine sulfoxide in proteins to protecting against oxidative damage. Among MSRs, MsrA subunit specifically reduces the $S$ form of both peptide-bound and free $\operatorname{Met}(0)$, and the $C$ terminal domain of MsrB also specifically reduced the $\mathrm{R}$ form of both peptide-bound and free Met(o) (Herbert et al., 2005; Shoshana 

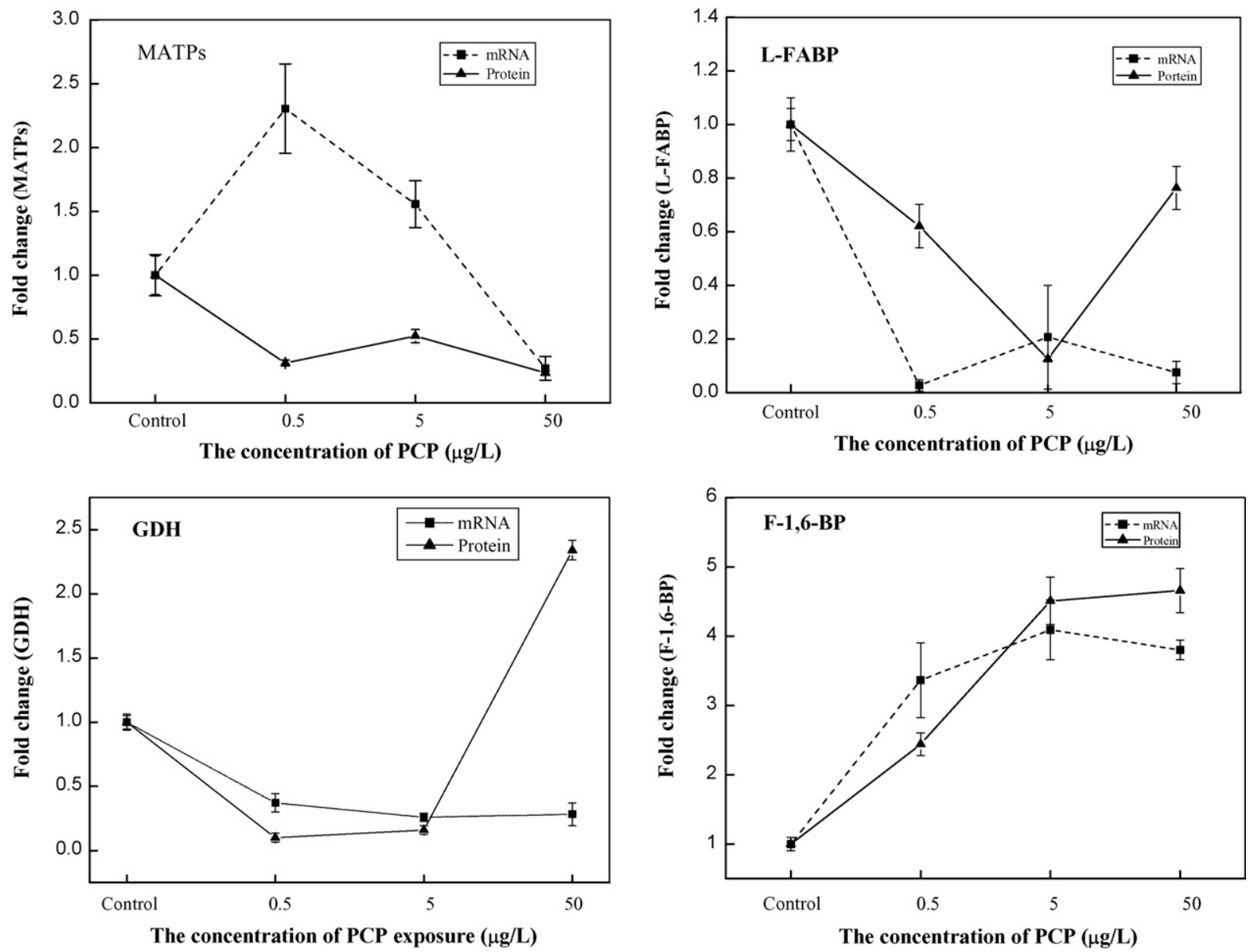

Fig. 6. The alteration of protein and mRNA expression of selected altered proteins in the livers of rare minnows following PCP treatments.

and Jackob, 2002). MSR was increased at the $0.5 \mu \mathrm{g} / \mathrm{L}$ (1.43-fold) and significant increased at $5 \mu \mathrm{g} / \mathrm{L}$ (4.43-fold) (Table 2) in male fish following PCP-treatment respectively, which indicated that MSR was up-regulated in order to protecting against oxidative damage, although decreased in the $50 \mu \mathrm{g} / \mathrm{L}$ in male fish, there was hardly any MSR protein in gel, this might because the production system of MSR was destroyed by PCP-treated, and there was no MSR in liver, so it might result in the oxidative damage. These results might evaluate the mechanisms of anti-oxidative in liver of rare minnows.

\subsection{Proteins related to other functions}

We also identified four protein spots involved in other functions in male and female samples following PCP exposure as follows: keratin 18 (K18), peptidyl arginine deiminase (PAD) and fhu operon transcription regulator.

Keratin intermediate filament proteins form cytoskeletal scaffolds in epithelia, the disruption of which affects cytoarchitecture, cell growth, survival, and organelle transport (Vijayaraj et al., 2009). Cytokeratin 18 (K18) is one of the type I keratin, the reduced expression of K18 in female fish following PCP exposure (spot f2) indicated that PCP might affect cytoarchitecture, which accorded with our results of transmission electron microscope (was not shown). Lack of keratin 18 might be the major reason of liver cell becoming round instead of inerratic, which might affect the space of cell, and then affect biology process that took place in cell.

Peptidyl arginine deiminase (PAD), type II (spot f7), which can catalyze the post-translational modification of proteins through the conversion of arginine to citrulline in the presence of calcium ions (Lundberg et al., 2005). The result shows that PAD was decreased in $0.5 \mu \mathrm{g} / \mathrm{L}$ and $5 \mu \mathrm{g} / \mathrm{L}$ PCP-treated groups, but the abundance was almost recovered in the $50 \mu \mathrm{g} / \mathrm{L}$ group (Fig. 3D). This might affect post-translational modification of proteins and significantly altered PAD might induce the modification of proteins through the conversion of arginine to citrulline. Furthermore, destroy function and biological processes might be one of the mechanisms of damage caused by PCP-treated.

Fhu operon transcription regulator is a regulator of the transcription of ferrichrome-uptake (fhu) operon (Xiong et al., 2000). Ferrichrome is a cyclic peptide consisting of three residues of delta-N-hydroxy-delta-N-acetylornithine, which acts as an iron transport agent. The expression of fhu operon transcription regulator (spot f16) was down-regulated in $0.5 \mu \mathrm{g} / \mathrm{L}$ and $5 \mu \mathrm{g} / \mathrm{L}$ PCP-treated groups, but was up-regulated in $50 \mu \mathrm{g} / \mathrm{L}$ PCP-treated groups (2.36-fold) (Table 2 ). These results suggest that iron transport in the liver of rare minnow might be reduced following $0.5 \mu \mathrm{g} / \mathrm{L}$ and $5 \mu \mathrm{g} / \mathrm{L}$ PCP exposure, while fish was treated with $50 \mu \mathrm{g} / \mathrm{L} \mathrm{PCP}$, iron transport was an up-regulator. Furthermore, iron transport took part in a variety of biology processes and as a regulator in most of biochemical progresses. Reduction of the ability of iron transport would affect ferrichrome-uptake after PCP treatment. The mechanisms of iron transport alteration caused by PCP exposure need further studies.

In summary, we used proteomic analysis to describe the hepatic protein profile of rare minnows following PCP exposure. Besides, QRT-PCR was used to detect the corresponding mRNA levels (L- 
FABP, F-1,6-BP, MATPs and GDH). A number of proteins were altered significantly in abundance with different doses of PCP exposure, some of them (12 proteins spots in female and 6 proteins in male fish) were identified successfully using MALDI-TOF-MS and MALDI-TOF/TOF-MS. These proteins were involved in multiple functions and took part in a variety of biological processes, including transport (steroid sulfotransferase-like protein, L-FABPs, MATPs), metabolism (sarcosine oxidase, GDH and F-1,6-BP), oxidative stress (NKEF and MSR) and other biological processes (keratin 18 , peptidyl arginine deiminase and fhu operon transcription regulator). Some of them were observed to be potential biomarkers in toxicological studies of rare minnows following PCP exposure as their dramatic altering and took part in a variety of important biological process, such as MATPs, as a key component of mitochondrial energy conversion in the mammalian organism, it produces most of the cellular ATP in aerobic cells; L-FABPs are capable of facilitating the solubility and intracellular transport of fatty acids; sulfonation is a key step in xenobiotic metabolism; GDH catalyzes the oxidative deamination of glutamate to alphaketoglutarate which was involved in the production of glucose by gluconeogenesis; MSR is an enzyme which can reduce methionine sulfoxide in proteins by protecting against oxidative damage. Furthermore, gender differences in protein and discrepancy of gene and protein expression need further studies. This work will provide the basis for grope the potential mechanisms of toxicity of PCP, which should be the main focus of studies on the mechanism of PCP toxicity in the future.

\section{Conflict of interest statement}

The author declares that there are no conflicts of interest.

\section{Acknowledgments}

We thank Prof. Zijian Wang (State Key Laboratory of Environmental Aquatic Chemistry, Research Center for Eco-Environmental Sciences, Chinese Academy of Sciences, Beijing, China) for his instruction and providing the rare minnows. This research was supported by the National Natural Science Foundation of China (No. 20707039).

\section{References}

Amita, L., Rajpal, S., Kashyap, B., Atya, K., Sanjeev, G., Hemant, J.P., Hatim, F.D., Giridhar, M.T., 2008. Modulation of signal transduction pathways in lymphocytes due to sub-lethal toxicity of chlorinated phenol. Toxicol. Lett. 179, 23-28.

ATSDR, 2001. Toxicological profile for pentachlorophenol. Agency for Toxic Substances and Disease Registry. Public Health Service, U.S. Department of Health and Human Services, Atlanta, GA, p. 316.

Bass, N.M., 1990. Fatty acid-binding protein expression in the liver: its regulation and relationship to the zonation of fatty acid metabolism. Mol. Cell Biochem. 98, 167-176.

Charles, A.S., 2004. Hyperinsulinism/hyperammonemia syndrome: insights into the regulatory role of glutamate dehydrogenase in ammonia metabolism. Mol. Genet. Metab. 81, S45-S51.

Chen, J., Jiang, J., Zhang, F., Yu, H., Zhang, J., 2004. Cytotoxic effects of environmentally relevant chlorophenols on L929 cells and their mechanisms. Cell Biol. Toxicol. 20, 183-196.

Chen, Z.W., Hassan-Abdulah, A., Zhao, G., Jorns, M.S., Mathews, F.S., 2006. Heterotetrameric sarcosine oxidase: structure of a diflavin metalloenzyme at $1.85 \mathrm{~A}$ resolution. J. Mol. Biol. 360, 1000-1018.

Chhabra, R., Maronot, R., Bucher, J., Haseman, J., Toft, J., Hejtmancik, M., 1999. Toxicology and carcinogenesis studies of pentachlorophenol in rats. Toxicol. Sci. 48, 14-20.

Chlumsky, L.J., Zhang, L., Jorns, M.S., 1995. Sequence analysis of sarcosine oxidase and nearby genes reveals homologies with key enzymes of folate one-carbon metabolism. J. Biol. Chem. 270, 18252-18259.

Coughtrie, M.W.H., 1996. Sulphation catalysed by the human cytosolic sulphotransferases-chemical defence or molecular terrorism. Hum. Exp. Toxicol. 15, 547-555.

Dowling, V.A., Sheehan, D., 2006. Proteomics as a route to identification of toxicity targets in environmental toxicology. Proteomics 6, 5597-5604.
Falany, C.N., 1991. Molecular enzymology of human liver cytosolic SULTs. Trends Pharmacol. Sci. 12, 255-259.

Fernández Freire, P., Labrador, F.V., Pérez Martìn, J.M., Hazen, M.J., 2005. Cytotoxic effects in mammalian vero cells exposed to pentachlorophenol. Toxicology 210 37-44.

Gregory, G.M., Barbara, P.A., Avery, L.M., John, T.M., Ann, B.K., Friedhelm, S., 2006 Liver fatty acid binding protein gene ablation potentiates hepatic cholesterol accumulation in cholesterol-fed female mice. Am. J. Physiol. Gastrointest. Liver Physiol. 290, G36-G48.

Hanstein, W.G., 1976. Uncoupling of oxidative phosphorylation. Biochim. Biophys. Acta 456, 129-148.

Herbert, W., Lionel, R., Nathan, B., 2005. Methionine sulfoxide reductases: history and cellular role in protecting against oxidative damage. Biochim. Biophys. Acta 1703, 203-212.

Hurk, V.D.P., Kubiczak, G.A., Lehmler, H.J., James, M.O., 2002. Hydroxylated polychlorinated biphenyls as inhibitors of the sulfation and glucuronidation of 3-hydroxybenzo[a]pyrene. Environ. Health Perspect. 110, 343348.

Jaume, F., Marc, Y.V., Daniel, A., Aureli, V.T., Meritxell, B., Marta, L., Francesc X.S., Victor, R., Antoni, C., Merce, P., 2009. Evaluation of pathways involved in pentachlorophenol-induced apoptosis in rat neurons. Neurotoxicology 30 , 451-458.

Josef, Houštěk, Andrea, Pícková, Alena, Vojtîšková, Tomáš, Mráček, Petr, Pecina Pavel, Ješina, 2006. Mitochondrial diseases and genetic defects of ATP synthase. Biochim. Biophys. Acta (BBA)--Bioenergetics 1757, 1400-1405.

Judith, Storch, Alfred, E.A.T., 2000. The fatty acid transport function of fatty acidbinding proteins. Biochim. Biophys. Acta 1486, 28-44.

Juhl, U., Witte, I., Butte, W., 1985. Metabolism of pentachlorophenol to tetrachlorohydroquinone by human liver homogenate. Bull. Environ. Contam. Toxicol. 33, 596-601.

Julie, C., Brodeur, D., George, D., Scott, R., McKinley, 2001. Inhibition of oxygen consumption by pentachlorophenol and tetrachloroguaiacol in rainbow trout (Oncorhynchus mykiss). Aquat. Toxicol. 54, 143-148.

Jurgella, G.F., Marwah, A., Malison, J.A., Peterson, R., Barry, T.P., 2006. Effects of xenobiotics and steroids on renal and hepatic estrogen metabolism in lake trout. Gen. Comp. Endocrinol. 148, 273-281.

Kimie, S., Kyung-Sun, K., Akihiko, H., Ryuichi, H., James, E.T., Tohru, I., 2001. Inhibition of apoptosis by pentachlorophenol in v-myc-transfected rat liver epithelia cells: relation to down-regulation of gap junctional intercellular communication. Cancer Lett. 173, 163-174.

Lu, L., Shen, Y.W., 2002. Acute toxicity of phenol, alkyl benzene, nitrobenzene and water sample to sword fish (Xiphophorus helleri) and rare minnow. Res. Environ. Sci. 15, 57-59 (in Chinese).

Luebker, D.J., Hansen, K.J., Bass, N.M., Butenhoff, J.L., Seacat, A.M., 2002. Interactions of fluorochemicals with rat liver fatty acidbinding protein. Toxicology 176 , 175-185.

Lundberg, K., Nijenhuis, S., Vossenaar, E.R., Palmblad, K., Klareskog, L., Zendman, A.J., Harris, H.E., 2005. Citrullinated proteins have increased immunogenicity and arthritogenicity and their presence in arthritic joints correlates with disease severity. Arthritis Res. Ther. 7, 458-467.

McConnachie, P.R., Zahalsky, A.C., 1991. Immunologic consequences of exposure to pentachlorophenol. Arch. Environ. Health 46, 249-253.

Merrick, B.A., Bruno, M.E., 2004. Genomic and proteomic profiling for biomarkers and signature profiles of toxicity. Curr. Opin. Mol. Ther. 6, 600-607.

Ohkimoto, K., Liu, M.Y., Suiko, M., Sakakibara, Y., Liu, M.C., 2004. Characterization of a zebrafish estrogen-sulfating cytosolic sulfotranferase: inhibitory effects and mechanism of action of phytoestrogens. Chem. Biol. Interact. 141, 1-7.

Plaitakis, A., Zaganas, I., 2001. Regulation of human glutamate dehydrogenases: implications for glutamate, ammonia and energy metabolism in brain. J. Neurosci. Res. 66, 899-908.

Proudfoot, A., 2003. Pentachlorophenol poisoning. Toxicol. Rev. 22, 3-11.

Renner, G., Hopfer, C., 1990. Metabolic studies on pentachlorophenol (PCP) in rat. Xenobiotica 20, 573-582.

Roberts, H.J., 1990. Pentachlorophenol-associated aplastic anaemia red cell aplasia leukaemia and other blood disorders. J. Florida Med. Assoc. 77, 86-90.

Sai-kato, K., Umemura, T., Takagi, A., Hasegawa, R., Tanimurat, A., Kurokawa, Y., 1995. Pentachlorophenol-induced oxidative DNA damage in mouse liver and protective effect of antioxidants. Food Chem. Toxicol. 33 (10), 877-882.

Shoshana, B.N., Jackob, M., 2002. Mouse methionine sulfoxide reductase B: effect of selenocysteine incorporation on its activity and expression of the selenocontaining enzyme in bacterial and mammalian cells. Biochem. Biophys. Res. Commun. 297, 956-961.

Strott, C.A., 2005. Sulfonation and molecular action. Endocrine Rev. 24, 703-732.

Thibaut, R., Porte, C., 2004. Effects of endocrine disrupters on sex steroid synthesis and metabolism pathways in fish. J. Steroid Biochem. Mol. Biol. 92, 485-494.

Vijayaraj, P., Kröger, C., Reuter, U., Windoffer, R., Leube, R.E., Magin, T.M., 2009. Keratins regulate protein biosynthesis through localization of GLUT1 and upstream of AMP kinase and raptor. J. Cell Biol. 187, 157-159.

Villena, F., Montoya, G., Klaasen, R., Fleckenstein, R., Suwalsky, M., 1992. Morphological changes on nerves and histopathological effects on liver and kidney of rats by pentachlorophenol (PCP). Comp. Biochem. Physiol. Part C: Comp. Pharmacol. 101 (2), 353-363.

Wang, J.L., Liu, D.X., Zhang, Z.J., Shan, S.M., Han, X.B., Srinivasa, M.S., Carlo, M.C., Emad, S.A., Huang, Z.W., 2000. Structure-based discovery of an organic compound that binds Bcl-2 protein and induces apoptosis of tumor cells. PNAS 97, 71247129 
Wang, L.Q., James, M.O., 2006. Inhibition of sulfotransferases by xenobiotics. Curr. Drug Metab. 7, 83-104.

Wang, Y.J., Lin, J.K., 1995. Estimation of selected phenols in drinking water with in situ acetylation and study on the DNA damaging properties of polychlorinated phenols. Arch. Environ. Contam. Toxicol. 28, 537-542.

Wang, L.Q., Margaret, O.J., 2007. Sulfonation of $17 \beta$-estradiol and inhibition of sulfotransferase activity by polychlorobiphenylols and celecoxib in channel catfish Ictalurus punctatus. Aquat. Toxicol. 81, 286-292.

Wei, Y.H., Wang, J.S., Zhang, X.W., Dai, J.Y., 2007. Identification and characterization of expressed sequence tags from the liver of rare minnow (Gobiocypris rarus). Comp. Biochem. Physiol., Part D 2, 356-362.

Wetmore, B.A., Merrick, B.A., 2004. Toxicoproteomics: proteomics applied to toxicology and pathology. Toxicol. Pathol. 32, 619-642.

WHO, 1987. Pentachlorophenol. In: Environmental Health Criteria, vol. 71. World Health Organization, Geneva.

William, H.D., Hallett, W.J., Murphy, 2006. Positive and negative regulation of natural killer cells: therapeutic implications. Seminars Cancer Biol. 16, 367382.

Xiong, A.M., Vineet, K.S., Guillermo, C., Radheshyam, K.J., 2000. Molecular characterization of the ferric-uptake regulator, Fur, from Staphylococcus aureus. Microbiology 146, 659-668.
Yin, Daqiang, Gu, Ying, Li, Yan, Wang, Xiaolin, Zhao, Qingshun, 2006. Pentachlorophenol treatment in vivo elevates point mutation rate in zebrafish p53 gene. Mutat. Res. 609, 92-101.

Zha, J.M., Wang, Z.J., Ingersoll, C., 2007. Histological alternation and vitellogenin induction in adult rare minnow (Gobiocypris rarus) after exposure to ethynylestradiol and nonylphenol. Chemosphere 66, 488-495.

Zhang . H., Evenhuis, J.P. Thorgaard, G.H., Ristow, S.S. 2001. Cloning characterization and genomic structure of the natural killer cell enhancement factor (NKEF)-like gene from homozygous clones of rainbow trout (Oncorhynchus mykiss). Dev. Comp. Immunol. 25, 25-35.

Zhang, M., Yin, D.Q., Kong, F.X., 2008. The changes of serum testosterone leve and hepatic microsome enzyme activity of crucian carp (Carassius carassius) exposed to a sublethal dosage of pentachlorophenol. Ecotoxicol. Environ. Saf. 71, 384-389.

Zhou, Y., Cheng, S., Hu, W., Sun, M., 1995. A new toxicity test organism--Gobiocypris rarus. Zool. Res. 16, 59-63.

Zimmerman, A.W., Moerkerk, V., Veerkamp, H.T., 2001. Ligand specificity and conformational stability of human fatty acidbinding proteins. Int. J. Biochem. Cell Biol. 33, 865-876. 